\title{
A dynamical approach to study the time dependent behavior of the Kuhbanan fault zone (Kerman - Iran)
} MOHAMMADREZA TAVAKOLI ${ }^{1}$, HOSEIN AMIRI ${ }^{1}$.

${ }^{1}$ Physics Department, Shahid Bahonar University of Kerman, Kerman, Iran.

Correspondence to: MOHAMMADREZA TAVAKOLI (mtavakoli69@ yahoo.com)

5 Abstract. In this research a proposed methodology is improved to identify how the stresses increase between two Earthquakes in Kuhbanan fault zone (Iran). Using the Mohr circles of the Earthquake we could calculate the main stress $\left(\sigma_{1}\right)$, hydrostatic stress, normal and shear stresses and the initial and final Coulomb stresses for all individual Earthquakes. For the relation of the whole fault we need the initial and the final Coulomb stress as well as the time during which the stress reaches from initial value to the final Coulomb failure value. The initial Coulomb stress is chosen as the least value, to be 30 megapascal. For the final Coulomb stress we used the average final Coulomb stress of all Earthquakes and for the time between this two initial and final stress we use the average time between Earthquake that is 3377 days. Using the Coulomb stresses at selected times, one can see how the stress increase with time between Earthquakes. The best fit of points of stress versus time is a polynomial relation. The model will help to estimate the stress accumulation with time until the next event, this means one can estimate the approaching time to the next main shock.

Keywords. Kuhbanan fault zone, stress accumulation, Coulomb stress, failure diagram, fault failure.

\section{Introduction}

The relation between Earthquake parameters and seismic prediction have been under consideration for long time. The concept of stress came to the theory of elasticity by Cauchy (1822) defined as force per unit area applied to a body. It was then extensively used as an essential application in design and engineering analysis. This concept was so important and essential because there was no possible direct way of measurement and no signs of stress in a continuum body under stress. Clearly, the way of transmission of force in continuum solids is completely different from those of liquidus (Kumar, 1998).

The elastic rebound model of Earthquake recurrence using geodetic observations from the 1906 San Francisco Earthquake has been developed by Reid (Reid, 1910). The idea is conceptually valuable in that it captures the relationship between strain accumulation (now known to result from plate motions) and Earthquake occurrence.

There are three basic models for Earthquake prediction (Lay and Wallace, 1995): the characteristic Earthquake, the time-predictable Earthquake and the slip-predictable Earthquake. A section of the San Andreas fault near Park field, California may be one example of a fault that follows the characteristic Earthquake model. This fault segment has had several M>6 Earthquakes with a mean recurrence interval of 22 years since 1857 (e.g. Bakun and Lindh, 1985). The time-predictable model assumes that fault strength is constant and that the fault will always rupture when the shear stress reaches final level. This model assumes that a large slip on the fault will reduce the level of shear stress more than a small slip. The Calaveras fault near San Francisco Bay, California appears to have time-predictable behavior over at least the short time window of observation from 1962-1977 (Bufe and others, 1977). Several 
Nat. Hazards Earth Syst. Sci. Discuss., doi:10.5194/nhess-2017-1, 2017

Manuscript under review for journal Nat. Hazards Earth Syst. Sci.

Discussion started: 27 February 2017

(c) Author(s) 2017. CC-BY 3.0 License.

In the slip-predictable model, the fault does not rupture at the same shear stress, each time. This model cannot be used to predict when rupture will occur, but it can be used to predict the magnitude of the Earthquake that would occur at any given time. After an Earthquake, stress on the fault will increase at a constant rate. The potential fault slip at any time is proportional to the shear stress on the fault. Thus, if the time of the last rupture is known, the shear stress on the fault and the potential displacement can be determined at any particular time.

Yet, several studies have shown that the time-predictable model was found far better for seismic hazard estimation and Earthquake prediction compared to the slip-predictable model (Sykes and Quittmeyer, 1981).

After lengthy work in the field of Earthquake recurrence models, the researchers have developed another model called the magnitude-predictable model. This model gives the relation between the magnitudes of the preceding and the following Earthquake and indicates that the larger the magnitude of the preceding mainshock, the smaller the magnitude of the following mainshock (Papazachos, 1992).

Soon after this, the time-predictable and magnitude-predictable models were combined to a single one called the regional time- and magnitude-predictable seismicity model, which holds for seismogenic regions (or sources) including the main fault and other smaller faults (Papazachos and Papaioannou, 1993).

In this research we tried to obtain initial and final stresses and a new approach to calculate stresses with time before Earthquakes, to roughly estimate the time zone of failure stress that is the time of hazardness.

\section{Methods and calculations}

In this research, we consider all Earthquakes with magnitude of 5 and more in Kuhbanan fault zone (Kerman - Iran) with longitude of $56.00^{\circ}$ to $57.50^{\circ}$ and latitude of $30.50^{\circ}$ to $32.00^{\circ}$ during 1900 to 2014 . We filtered the Earthquake because for some Earthquakes we need to calculate the slope fault for which one need quakes with s file. For such these cases we choose the Earthquake of 5 and more magnitude. On the other hand such Earthquake have considerable failure stresses than small Earthquakes.

As in the map (fig. 1), there are 15 events with magnitude 5 and more in this zone, we found only 12 Earthquakes particularity on Kuhbanan fault as there are other faults on this zone. These are collected in Table 1.

Some specification of Earthquakes like depth (focal depth) and dip (regional dip of fault) are from other sources than ISC (Table 1). In some cases these are calculated in this work. For example, specification of Earthquakes of 2005 is used from Talebian (Talebian et al., 2006), for Earthquakes in 1977 and 1984 from Baker (Baker, 1993). Also, in some of the Earthquake only one of these two quantities is being used from other sources, for example, for the depth of the Earthquake in 1933 we used the work by Berberian (Berberian, 1976) but the dip of this Earthquake is calculated in this work.

When shear or normal stresses are sufficiently applied to plates on two sides of a fault, failure will happen at a regional point and an Earthquake occurs. Applied stresses can be analyzed by using Mohr circle diagrams. As an example, Terakawa and his colleagues (Terakawa et al., 2010) have found shear and normal stresses for the 6th

70 April 2009 L'Aquila Earthquake with 6.4 magnitude by using Mohr circle. In this area with coefficient of friction $(\mu) 0.6$ and Coulomb failure line dip with normal stress about 60 degrees, the applied shear and normal stresses are 
Nat. Hazards Earth Syst. Sci. Discuss., doi:10.5194/nhess-2017-1, 2017

Manuscript under review for journal Nat. Hazards Earth Syst. Sci.

Discussion started: 27 February 2017

(c) Author(s) 2017. CC-BY 3.0 License.

found to be 51 and 197 megapascals (MPa) respectively. But what is considerable, is that Terakawa and his colleagues calculated stresses only at the time of Earthquake. This will make our work different, calculating stresses applied gradually during times before Earthquakes.

To calculate the accumulative stresses before the Earthquake we used the total stress as Eq. (1) known as Coulomb stress.

$C F F=\tau_{n}+\mu\left(\sigma_{n}+P\right)$

Where CFF is Coulomb stress, $\tau_{n}$ is shear stress, $\sigma_{n}$ is normal stress (combination of hydrostatic pressure and tectonic stress), $\mu$ is coefficient of friction usually about 0.6 and $\mathrm{P}$ is pore or fracture pressure in the Earth's crust (e.

Pore fluid pressure $\mathrm{P}$ modifies the effective normal stress across the failure plane.

$P=-B \sigma_{n}$

where $B$ is known as Skepton coefficient between 0.5 and 0.9. Then the Coulomb stress will be

$C F F=\tau_{n}+\mu^{\prime} \times \sigma_{n}$

85 Where

$\mu^{\prime}=\mu(1-B)$

$\mu^{\prime}$ is the effective friction coefficient varies with crust properties. The values for the effective friction coefficient range between 0 and 0.75 (Yao-Lin and Jian-Ling, 2010; Cocco and Rice, 2002). We have used 0.4 as has been used in many calculations (e.g. Stein et al., 1992; King et al., 1994). We use the same model of calculation as L'Aquila

Earthquake by Terakawa and his colleagues (Terakawa et al., 2010). As an example, applied stresses on the fault in 2005 Earthquake can be calculated by its Mohr circle and using Eq. (3) that is known as Coulomb stress.

Using accumulated normal and shear stresses ( $\sigma_{n}$ and $\tau_{n}$ from Mohr circle of fig. 2) and effective friction coefficient of 0.4 in this Earthquake of 6.4 magnitude one can calculate Coulomb (final) stress as $C F F_{f}=32+0.4 \times 132 \cong 85 M P a$, We define

$95 \quad C F F_{i}=\mu^{\prime} \times P_{h}$

As initial Coulomb stress, where $P_{h}$ is fluid pressure equal to $75 \mathrm{MPa}$ (as shown in fig. 2). Initial Coulomb stress is found to be $30 \mathrm{MPa}$.

3 Coulomb stresses with time before Earthquakes

Using Coulomb failure diagrams, initial and final Coulomb stresses and average time difference between

Earthquakes; one can calculate the average Coulomb stress before each Earthquake during the past 100 years.

As in the 2005 Earthquake, we calculate the initial and final stresses for all Earthquakes with magnitude 5 and more in this fault zone. These stresses have been averaged separately in each Earthquake for all years of stress accumulation. One can calculate how much stress is necessary for an Earthquake of special magnitudes or an Earthquake with this same magnitude will be occurred if such this stress be applied on the fault. A property of this method is that one can estimate how much stress is accumulated at any time such as the time of the study.

Firstly, we consider that at any Earthquake time, there is a stress release and for the next Earthquake there should be an applied stress greater than the remained stress of this one. The stress drop is calculated as the following steps;

For the strike - slip fault 
Nat. Hazards Earth Syst. Sci. Discuss., doi:10.5194/nhess-2017-1, 2017

Manuscript under review for journal Nat. Hazards Earth Syst. Sci.

Discussion started: 27 February 2017

(c) Author(s) 2017. CC-BY 3.0 License.

In this two Eq. (6) and (7), $\mu$ is shear modulus, $\lambda$ is Lame coefficient, $w$ is seismic layer thickness (the most focal depth of Earthquakes), and $\bar{D}$ is the amount of displacement during an Earthquake (Zare, 2005). We assume that the amount of displacement changes from 1 to $100 \mathrm{~cm}$, seismic layer thickness is $33 \mathrm{~km}$ (ISC website), and $\mu$ and $\lambda$ to be 34.327 and 31.745 GPa respectively (Khajuyi et al., 2003). Fig. 1, shows the fault is both strike - slip and dip slip fault. So we may use the mean value of $\Delta \sigma$ in these equations (6 and 7).

These amounts of stress drop (0.00742, 0.0742 and $0.742 \mathrm{MPa}$ for displacements 1,10 and $100 \mathrm{~cm}$ respectively) are negligible comparing with final Coulomb stress of, e.g. 2005 Earthquake that is $85 \mathrm{MPa}$. This means that variation in the initial stresses are very minor. Even with displacement of $1 \mathrm{~m}$ it becomes $0.742 \mathrm{MPa}$ that is negligible in comparison to the increasing from 30 to $85 \mathrm{MPa}$. Here, we average the failure stresses $\left(\tau_{S}\right)$ and pressure (hydrostatic stress calculated by using Mohr circles). Finally, one can find the average time between events. We use the first part of the diagram to obtain the stress before Earthquakes (as show in fig. 3).

These tow averaged stresses can be chosen as star points on the graph (fig. 3(b)). The horizontal axis is time, starts at zero and continue to the average time of the events (the average of failure time difference). The vertical axis would be Coulomb stress, started at the initial stress (pressure fluid) continued to the highest Coulomb stress (failure stress), see Table 2. The average failure time can be the average time difference between the events shown in the Table 1. The time differences of these events are shown in Table 2.

The average of these time differences is 9.04 .02 (equal to 3377 days) that means on average every nine years, four months and two days there had been Earthquake of 5 and more magnitude in this fault zone. This is the average period time of such events in this fault. One can says that according to the statistical average of 100 years, there may be an event with such magnitude up to 2021, because the last one has been occurred in 2012.12.03. Otherwise, the next event should be greater in magnitude or focal depth.

The Mohr circles for all Earthquakes with different focal depth can be drown similar to the one with $7 \mathrm{~km}$ depth (fig. 4). With these Mohr circles we can calculate the principal, initial and final stresses (Table 3). Accordingly, the initial stresses in each event may be different because of differences in focal depths.

For the failure graph of the fault, what we basically need is the initial and final points, shown as star points on the fig. 3(b). We do not have information about the initial Coulomb stress. For this, what may we do is, to use the average values of the initial stresses in the seventh column of Table 3. This is obtained to be approximately $81 \mathrm{MPa}$. But, this value is more than the final stresses of some Earthquakes such as 1987, so it cannot be considered as initial stresses, that is $30 \mathrm{MPa}$ (Table 3). For the final stress we can use the average Coulomb final stresses in the table, that is about $30 \mathrm{MPa}$. Now, according to the fig. 3(b) with stars points by using Plot Digitizer code (computer program), we can estimate the stresses with the time after the previous Earthquakes in the fault (Table 4), it is shown in fig. $5(a)$. 
Nat. Hazards Earth Syst. Sci. Discuss., doi:10.5194/nhess-2017-1, 2017

Manuscript under review for journal Nat. Hazards Earth Syst. Sci.

Discussion started: 27 February 2017

(c) Author(s) 2017. CC-BY 3.0 License.

\section{The model of stress accumulation}

Using these data such as in Table 4, now one can plot stress accumulation versus selected times after any Earthquake up to the next fault failure (fig. 5(a)).

In this graph one can see the stress process with time in the fault. Time and stress axes unit are days and MPa respectively. Time axis (horizontal axis) is started from time of the Earthquake until at least the average time of Earthquakes (calculated in accordance with Table 2) which is equal to 3377 days. The stress axis is started from initial stress according to equation (5) that equal to $30 \mathrm{MPa}$ and for the final stress, we average from eighth column table 3. In this figure, the stress rising rate is not so considerable for the first few months, but after some months the slope of rising stress is high that is in good agreement with the theoretical graph of Coulomb failure.

The best fitting curve of the scatter plot in fig. 5(a) using Mathematica, Excel and TableCurve programs is a polynomial curve showing stress accumulation in the fault between two Earthquakes (fig. 5(b)). This is in a good agreement with fig. 3(a) (theoretical Coulomb failure diagram). Accordingly, an equation that expresses this polynomial relation is

$P(t)=\left(a_{0}+a_{1} t+a_{2} t^{2}+a_{3} t^{3}+a_{4} t^{4}+a_{5} t^{5}\right)^{\frac{1}{2}}$.

In this relation $\mathrm{P}$ is Coulomb stress and $a_{0}, a_{1}, a_{2}, a_{3}, a_{4}$ and $a_{5}$ are constants related to the seismic parameter and $\mathrm{t}$ is the time after the previous Earthquake. By using Mathematica, Excel and TableCurve programs, we obtained the parameters as, $a_{0}=762.45735, a_{1}=2.9154157, a_{2}=-0.0089392707, a_{3}=1.0381355 \times 10^{-5}$, $a_{4}=-4.8867538 \times 10^{-9}$ and $a_{5}=8.2511543 \times 10^{-13}$, that means the desired polynomial relation for stress accumulation along this fault is:

$P(t)=\left(762.45735+2.9154157 t-0.0089392707 t^{2}+1.0381355 \times 10^{-5} t^{3}-4.8867538 \times 10^{-9} t^{4}+\right.$

$\left.8.2511543 \times 10^{-13} t^{5}\right)^{\frac{1}{2}}$.

The value of these parameters ( $a_{0}$ to $a_{5}$ ) may be influenced by any Earthquake location errors that may any how com to account. This may be due to changes of dip or depth of the Earthquakes. Although, fortunately technology these days help to find Earthquake locations with very negligible error.

Some other researches have tried to obtain relations between parameters such as stress, strain and energy versus time. Some logarithmic and even power law relationship are mentioned (e.g. Tzanis et al,. 2000; Tzanis and Vallianatos, 2003; Varnes, 1989). We may fit a logarithmic relation to the data in table 4, but for this active fault zone of our research, the form of relation such as equation (8) may have a better consistency with stress increase when there be no Earthquake for perhaps a longer time.

\section{Results}

175 A dynamical approach to study the time dependent behavior of Kuhbanan fault zone, based on seismic data of events with magnitude of 5 and more during the last 100 years, conduced to some new data and relation on this fault in south-east of Iran. The average time between Earthquakes is 3377 days. Drawing the Mohr circle of Earthquakes we found the main, initial and final stresses applied on the fault in each Earthquake, tabulated in Table 3. We could then, estimate the lowest and the average final Coulomb stress, on this fault during its last 100 years of seismic activities to be 30 and $190 \mathrm{MPa}$ respectively. The main and best result of this study is the average rate of stress 
Nat. Hazards Earth Syst. Sci. Discuss., doi:10.5194/nhess-2017-1, 2017

Manuscript under review for journal Nat. Hazards Earth Syst. Sci.

Discussion started: 27 February 2017

(c) Author(s) 2017. CC-BY 3.0 License.

accumulation up to the fault failure, tabulated in Table 4. The resultant time dependent stress accumulation along this fault is a polynomial relation (fig. 5 (b)), specified as the Eq. (9). By this Equation one may estimate the stress accumulated at any time after each Earthquake, as well as the hazardness time zone of the fault.

\section{References}

Baker, C.: The active seismicity and tectonics of Iran, PhD thesis, (unpublished), University of Cambridge, pp. 228, 1993.

Bakun, W.H. and Lindh, A.G.:The Parkfield, California, Earthquake prediction experiment, Science, 229(4714), 619-624, 1985.

Berberian, M.: Documented Earthquake faults in Iran, Geol. Surv. of Iran., 39, 143-186, 1976.

Berberian, M.: areas of destructive Earthquakes in Iran, Geol. Surv. of Iran., 4th centery B.C. to 1976. A.D, 39 pp., 1976.

Berberian, M., Jakson, J. A., Ghorashi, M. and Kadjar, M. H.: Field and teleseismic observations of the 1981 Golbaf-Sirch Earthquakes in SE Iran, Geophysical Journal International, 77, 809 -838, 1984.

Bufe, C.G., Harsh, P.W. and Durford, R.O.: Steady state seismic slip - A precise recurrence model, Geophysical

Research Letters, 4, 91-94, 1977.

Cocco, M. and Rice, J. R.: Pore pressure and poroelasticity effects in Coulomb stress analysis of Earthquake interactions, Journal of Geophysical Research, 107(B2), ESE.2.1-ESE.2.17, doi: 10.1029/2000JB000138, February 2002.

Khajuyi, R., manouchehri, M. F. and Riahi, A.: A model of fault stress distribution by finite element method in 1382

Bam Earthquake, Earthquake Research Center of Ferdowsi University of Mashhad, 2003, (inter university journal in main language).

King, G. C. P., Stein, R. S. and Lin, J.: Static stress changes and the triggering of Earthquakes, Bull. Seismol. Soc. Am., 84, 935-953, 1994.

Kumar, P.: Shear Failure Envelope of Hoek-Brown Criterion for Rockmass, Tunnelling and Underground Space

205 Technology, 13(4), 453-459, 1998.

Lay, T. and Wallace, T.C.: Modern global seismology, Academic Press, San Diego, California, pp. 521, 1995.

Miao, M. and Shou-Biao, Z.: A study of the impact of static Coulomb stress changes of Megathrust Earthquakes along subduction zone on the following aftershocks, Chinese Journal of Geophysics, 55(5), 539-551, 2012.

Mogi, K.: Earthquake Prediction, Academic Press, Tokyo, pp. 355, 1985.

210 Papazachos, B. C.: A time predictable model for Earthquake generation in Greece, Bull. Seismo. Soc. Am., 79, 7784, 1989.

Papazachos, B. C.: A time and magnitude predictable model for generation of shallow Earthquakes in the Aegean area, Pure Appl. Geophys., 138, 287-308, 1992.

Papazachos, B. C. and Papaioannou, Ch. A.: Long term Earthquake prediction in Aegean area based on a time- and 215 magnitudepredictable model, Pure Appl. Geophys., 140, 593-612, 1993.

Paudyal, H., Singh, H. N., Shankar, D. and Singh, V. P.: Validity of Time-Predictable Seismicity Model for Nepal and its Adjoining Regions, Journal of Nepal Geological Society, 38, 15-22, 2008. 
Nat. Hazards Earth Syst. Sci. Discuss., doi:10.5194/nhess-2017-1, 2017

Manuscript under review for journal Nat. Hazards Earth Syst. Sci.

Discussion started: 27 February 2017

(c) Author(s) 2017. CC-BY 3.0 License.

Reid, H. F.: The mechanism of the Earthquake, in: he California Earthquake of April 18, 1906, report of the state Earthquake Investigation Commission, vol. 2, Washington, D.C., Carnegie Institution, pp. 1-92, 1910.

Shanker, D.: Characteristic studies of tectonics, Seismicity and occurrences of major Earthquakes in northeast India, PhD Thesis, Banaras Hindu University, Varanasi, India, pp. 117, 1990.

Shanker, D. and Singh, V. P.: Regional Time- and Magnitudepredictable Seismicity model for north-east India and vicinity, Acta Geod. Geoph. Hung., 31(1-2), 181-190, 1996.

Shanker, D. and Singh, H. N.: Application of the time-predictable model in Peninsular India for future seismic hazard assessment, Acta Geophysica, 55(3), 302-312, 2007.

Stein, R. S., King, G. C. P. and Lin, J.: Change in failure stress on the southern San Andreas fault system caused by the 1992 magnitude = 7.4 Landers Earthquake, Science, 258, 1328-1332, 1992.

Sykes, L. R. and Quittmeyer, R. C.: Inter-event time of great Earthquakes along simple plate boundaries, in: Earthquake Prediction, An International review, edited by: Simpson, D. W. and Richards, P. G., Maurice Ewing Series, Amer. Geophys. Union., 4, 297-332, 1981.

Talebian, M., Biggs, J., Bolourchi, M., Copley, A., Ghassemi, A., Ghorashi, M., Hollingsworth, J., Jackson, J., Nissen, E., Oveisi, B., Parsons, B., Priestley, K. and Saiidi, A.: The Dahuiyeh (Zarand) Earthquake of 2005 February 22 in central Iran: reactivation of an intramountain reverse fault, Geophysical Journal International, 164, 137-148, doi: 10.1111/j.1365-246X.2005.02839.x, 2006.

235 Terakawa, T., Zoporowski, A., Galvan, B. and Miller, S. A.: High-pressure fluid at hypocentral depths in the L'Aquila region inferred from Earthquake focal mechanisms, Geology, 38, 995-998, doi: 10.1130/G31457.1, 2010.

Tzanis, A., Vallianatos, F. and Makropoulos, K.: Seismic and electric precursors to the 17-1-1983, M 7 Kefallinia earthquake, Greece: signatures of a SOC system, Phys. Chem. Earth (A), 25(3), 281-287, 2000.

Tzanis, A. and Vallianatos, F.: Distributed power-law seismicity changes and crustal deformation in the SW

240 Hellenic Arc, Natural Hazards and Earth System Sciences, 3, 179-195, 2003.

Varnes, D. J.: Predicting earthquakes by analyzing accelerating precursory seismic activity, Pure Appl. Geophys. 130(4), 661-686, 1989.

Yao-Lin, S. and Jian-Ling, C.: Some aspects of statics stress change calculation- case study on the Wenchuan Earthquake, Chinese Journal of Geophysics, 53(1), 64-73, 2010.

Zare, M.: Introduction to Applied Seismology, International Institute of Seismology and Earthquake Engineering, Iran. Tehran, 1th addition, pp. 304,(main language), 2005. 
Nat. Hazards Earth Syst. Sci. Discuss., doi:10.5194/nhess-2017-1, 2017

Manuscript under review for journal Nat. Hazards Earth Syst. Sci.

Discussion started: 27 February 2017

(c) Author(s) 2017. CC-BY 3.0 License.
Natural Hazards and Earth System Sciences

Discussions (c) (i)

\begin{tabular}{ccrccc}
\hline & Date & magnitude & $\begin{array}{c}\text { Focal } \\
\text { depth }(\mathbf{k m})\end{array}$ & $\begin{array}{c}\text { Dip } \\
(\text { degree })\end{array}$ & Source \\
\hline $\mathbf{1}$ & $1911 / 04 / 18$ & $6.7(\mathrm{MS})$ & 30 & 72 & {$[1,2]$, isc,cmt,here } \\
$\mathbf{2}$ & $1933 / 11 / 28$ & $6.2(\mathrm{MS})$ & 27 & 72 & {$[1], \mathrm{cmt}$, here } \\
$\mathbf{3}$ & $1977 / 12 / 19$ & $5.3(\mathrm{mb})$ & 7 & 82 & {$[3]$} \\
$\mathbf{4}$ & $1978 / 05 / 22$ & $5(\mathrm{mb})$ & 32 & 72 & {$[4]$, isc,here } \\
$\mathbf{5}$ & $1984 / 08 / 06$ & $5.6(\mathrm{mb})$ & 11 & 35 & {$[3]$} \\
$\mathbf{6}$ & $1987 / 04 / 11$ & $5(\mathrm{mb})$ & 9 & 90 & {$[4]$, isc,here } \\
$\mathbf{7}$ & $2002 / 04 / 05$ & $5(\mathrm{mb})$ & 33 & 72 & {$[4], \mathrm{cmt}$, here } \\
$\mathbf{8}$ & $2002 / 10 / 16$ & $5(\mathrm{mB})$ & 33 & 90 & {$[5]$} \\
$\mathbf{9}$ & $2005 / 02 / 22$ & $6.4(\mathrm{MS})$ & 7 & 60 & cmt,isc \\
$\mathbf{1 0}$ & $2006 / 05 / 07$ & $5(\mathrm{mb})$ & 12 & 73 & {$[5]$, here } \\
$\mathbf{1 1}$ & $2007 / 02 / 19$ & $5.1(\mathrm{mB})$ & 13 & 60 & here \\
$\mathbf{1 2}$ & $2012 / 12 / 03$ & $5(\mathrm{MN})$ & 13 & 65 & \\
\hline
\end{tabular}

Table 1. Earthquakes with magnitude 5 and more in Kuhbanan fault region ([1]: Berberian, 1976, [2]: Berberian, map, 1976, [3]: Baker, 1993, [4]: Berbriyan et al., 1984, [5]: Talebiyan et al., 2006). 
Nat. Hazards Earth Syst. Sci. Discuss., doi:10.5194/nhess-2017-1, 2017

Manuscript under review for journal Nat. Hazards Earth Syst. Sci.

Discussion started: 27 February 2017

(c) Author(s) 2017. CC-BY 3.0 License.

\begin{tabular}{cc}
\hline $\begin{array}{c}\text { Years of Earthquake } \\
\text { occurrence }\end{array}$ & $\begin{array}{c}\text { Time difference (in terms of } \\
\text { year/month/day) }\end{array}$ \\
\hline $1933-1911$ & 22.07 .10 \\
$1977-1933$ & 44.01 .22 \\
$1978-1977$ & 0.06 .03 \\
$1984-1978$ & 06.03 .17 \\
$1987-1984$ & 02.09 .06 \\
$2002.04 .05-1987$ & 14.12 .27 \\
$2002.10 .1-2002.04 .05$ & 0.07 .13 \\
$2005-2002.10 .16$ & 02.05 .09 \\
$2006-2005$ & 01.03 .15 \\
$2007-2006$ & 0.10 .15 \\
\hline
\end{tabular}

Table 2. The time difference between occurred Earthquakes with magnitude of 5 and more 
Nat. Hazards Earth Syst. Sci. Discuss., doi:10.5194/nhess-2017-1, 2017

Manuscript under review for journal Nat. Hazards Earth Syst. Sci.

Discussion started: 27 February 2017

(c) Author(s) 2017. CC-BY 3.0 License.

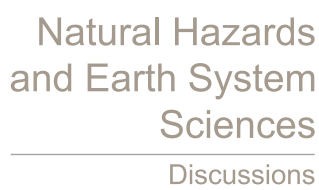

\begin{tabular}{|c|c|c|c|c|c|c|c|}
\hline & Date & magnitude & $\begin{array}{c}\text { Depth } \\
(\mathbf{k m})\end{array}$ & $\begin{array}{c}\text { The principal } \\
\text { stress }\left(\sigma_{1}\right) \\
(\mathrm{MPa})\end{array}$ & $\begin{array}{c}\text { Fluid } \\
\text { pressure } \\
\left(\boldsymbol{P}_{h}\right)(\mathrm{MPa})\end{array}$ & $\begin{array}{c}\text { Initial Coulomb } \\
\text { stress } \\
\left(C F F_{i}\right)(\mathbf{M P a})\end{array}$ & $\begin{array}{c}\text { Final Coulomb } \\
\text { stress } \\
\left(C F F_{f}\right)(\mathrm{MPa})\end{array}$ \\
\hline 1 & $1911 / 04 / 18$ & 6.7(MS) & 30 & 810 & 324 & 129 & 302 \\
\hline 2 & $1933 / 11 / 28$ & $6.2(\mathrm{MS})$ & 27 & 729 & 291 & 116 & 271 \\
\hline 3 & $1977 / 12 / 19$ & $5.3(\mathrm{mb})$ & 7 & 189 & 75 & 30 & 56 \\
\hline 4 & $1978 / 05 / 22$ & $5(\mathrm{mb})$ & 32 & 864 & 345 & 138 & 322 \\
\hline 5 & $1984 / 08 / 06$ & $5.6(\mathrm{mb})$ & 11 & 297 & 118 & 47 & 166 \\
\hline 6 & 1987/04/11 & $5(\mathrm{mb})$ & 9 & 243 & 97 & 39 & 58 \\
\hline 7 & $2002 / 04 / 05$ & $5(\mathrm{mb})$ & 33 & 891 & 356 & 142 & 332 \\
\hline 8 & $2002 / 10 / 16$ & $5(\mathrm{mB})$ & 33 & 891 & 356 & 142 & 214 \\
\hline 9 & $2005 / 02 / 22$ & $6.4(\mathrm{MS})$ & 7 & 189 & 75 & 30 & 85 \\
\hline 10 & $2006 / 05 / 07$ & $5(\mathrm{mb})$ & 12 & 324 & 130 & 52 & 118 \\
\hline 11 & 2007/02/19 & $5.1(\mathrm{mB})$ & 13 & 351 & 140 & 56 & 159 \\
\hline 12 & 2012/12/03 & $5(\mathrm{MN})$ & 13 & 351 & 140 & 56 & 148 \\
\hline
\end{tabular}

Table 3. The applied stresses in Earthquakes using Mohr circles. 
Nat. Hazards Earth Syst. Sci. Discuss., doi:10.5194/nhess-2017-1, 2017

Manuscript under review for journal Nat. Hazards Earth Syst. Sci.

Discussion started: 27 February 2017

(c) Author(s) 2017. CC-BY 3.0 License.
Natural Hazards

and Earth System

Sciences

Discussions

\begin{tabular}{|c|c|c|}
\hline $\begin{array}{c}\text { Number } \\
\text { of point } \\
\text { in the } \\
\text { code }\end{array}$ & $\begin{array}{l}\text { Time after previous } \\
\text { event (in terms of } \\
\text { year/month/day) }\end{array}$ & $\begin{array}{c}\text { Stress } \\
\text { accumulated } \\
(\mathrm{MPa})\end{array}$ \\
\hline 1 & 0.01 .01 & 30 \\
\hline 2 & 0.02 .14 & 30.41 \\
\hline 3 & 0.03 .31 & 30.42 \\
\hline 4 & 0.06 .28 & 30.43 \\
\hline 5 & 0.09 .26 & 30.6 \\
\hline 6 & 0.12 .25 & 30.86 \\
\hline 7 & 1.03 .25 & 31.3 \\
\hline 8 & 1.06 .22 & 31.75 \\
\hline 9 & 1.09 .20 & 32.21 \\
\hline 10 & 1.12 .19 & 32.66 \\
\hline 11 & 2.03 .12 & 33.13 \\
\hline 12 & 2.06 .22 & 33.6 \\
\hline 13 & 2.09 .14 & 34.08 \\
\hline 14 & 2.12 .13 & 34.56 \\
\hline 15 & 3.03 .12 & 35.05 \\
\hline 16 & 3.06 .10 & 35.55 \\
\hline 17 & 3.09 .08 & 36.05 \\
\hline 18 & 3.12 .07 & 36.56 \\
\hline 19 & 4.03 .06 & 37.08 \\
\hline 20 & 4.05 .30 & 39.21 \\
\hline 21 & 4.09 .01 & 40.32 \\
\hline 22 & 4.11 .29 & 42.04 \\
\hline 23 & 5.02 .26 & 44.44 \\
\hline 24 & 5.05 .25 & 46.97 \\
\hline 25 & 5.08 .23 & 48.95 \\
\hline
\end{tabular}

\begin{tabular}{|c|c|c|}
\hline 26 & 5.11 .19 & 51.71 \\
\hline 27 & 6.02 .16 & 55.38 \\
\hline 28 & 6.05 .16 & 58.49 \\
\hline 29 & 6.08 .13 & 61.76 \\
\hline 30 & 6.11 .10 & 64.33 \\
\hline 31 & 7.02 .06 & 68.84 \\
\hline 32 & 7.05 .06 & 73.65 \\
\hline 33 & 7.08 .02 & 82.03 \\
\hline 34 & 7.10 .28 & 94.56 \\
\hline 35 & 8.01 .23 & 110.21 \\
\hline 36 & 8.04 .20 & 123.85 \\
\hline 37 & 8.07 .16 & 142.84 \\
\hline 38 & 8.08 .29 & 148.51 \\
\hline 39 & 8.10 .12 & 156.41 \\
\hline 40 & 8.11 .25 & 162.62 \\
\hline 41 & 9.1 .09 & 169.07 \\
\hline 42 & 9.02 .04 & 172.51 \\
\hline 43 & 9.02 .08 & 173.51 \\
\hline 44 & 9.02 .12 & 175.77 \\
\hline 45 & 9.02 .21 & 178.07 \\
\hline 46 & 9.03 .02 & 180.39 \\
\hline 47 & 9.03 .06 & 182.75 \\
\hline 48 & 9.03 .11 & 185.13 \\
\hline 49 & 9.03 .20 & 187.55 \\
\hline 50 & 9.04 .02 & 190 \\
\hline
\end{tabular}

Table 4. Stress accumulation with time before Earthquake, this should be the time after the pervious event. 
Nat. Hazards Earth Syst. Sci. Discuss., doi:10.5194/nhess-2017-1, 2017

Manuscript under review for journal Nat. Hazards Earth Syst. Sci.

Discussion started: 27 February 2017

(c) Author(s) 2017. CC-BY 3.0 License.

\section{Natural Hazards and Earth System \\ Sciences \\ Discussions}

\section{(c) (1)}

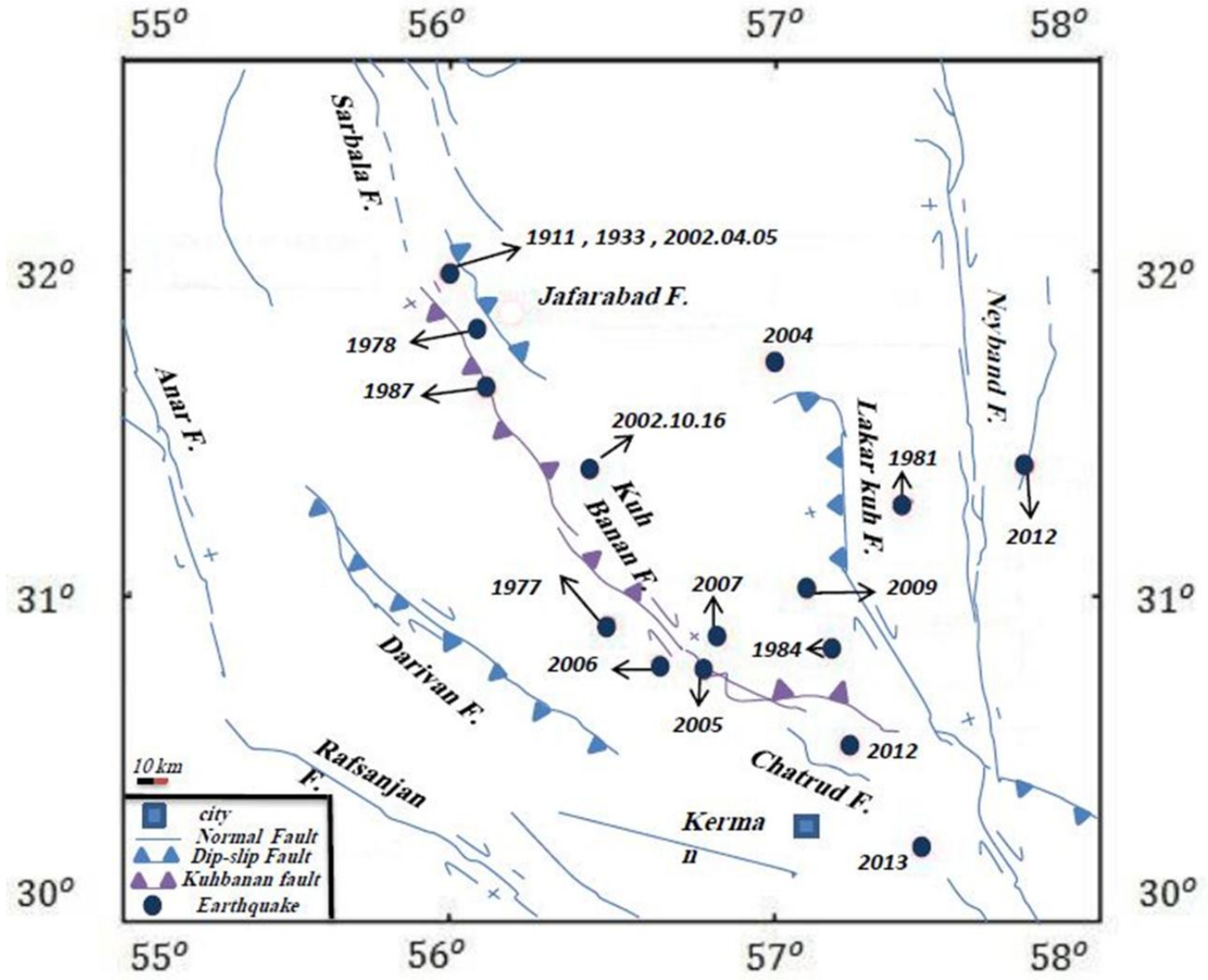

Figure 1. Earthquakes in fault zone with longitude of $55-58$ and latitude of 30-33 degrees in period time of 1900 to 2014. 
Nat. Hazards Earth Syst. Sci. Discuss., doi:10.5194/nhess-2017-1, 2017

Manuscript under review for journal Nat. Hazards Earth Syst. Sci.

Discussion started: 27 February 2017

(c) Author(s) 2017. CC-BY 3.0 License.

(c) (i)

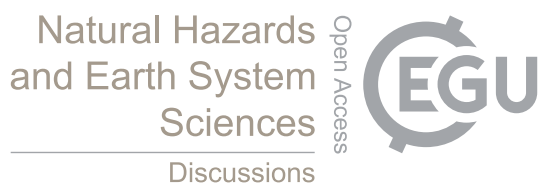

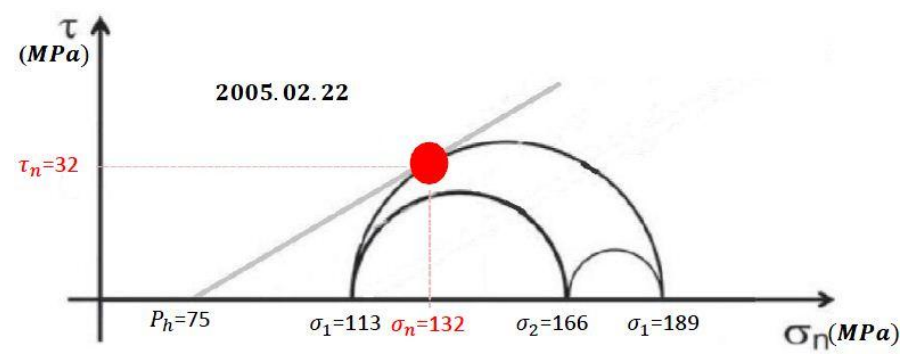

Figure 2. Stress circle and failure line for depth of $7 \mathbf{~ k m}$ 
Nat. Hazards Earth Syst. Sci. Discuss., doi:10.5194/nhess-2017-1, 2017

Manuscript under review for journal Nat. Hazards Earth Syst. Sci.

Discussion started: 27 February 2017

(C) Author(s) 2017. CC-BY 3.0 License.

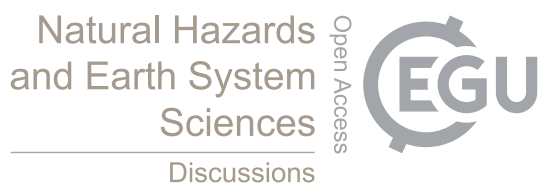

(c) (i)

(b)

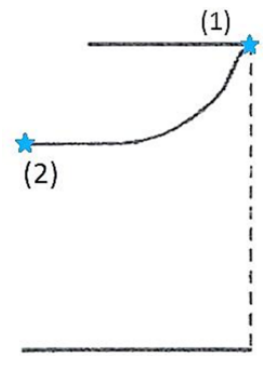

(a)

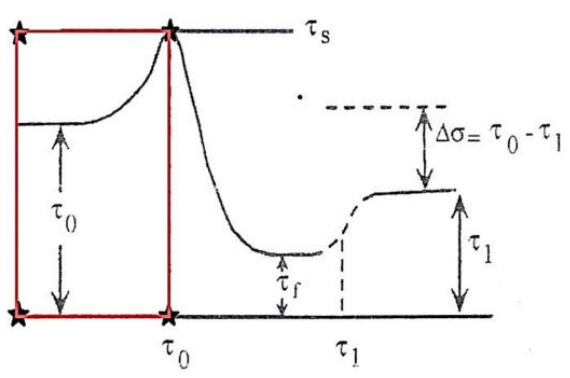

Figure 3. Coulomb failure diagram and special diagram to calculate the stress. 
Nat. Hazards Earth Syst. Sci. Discuss., doi:10.5194/nhess-2017-1, 2017

Manuscript under review for journal Nat. Hazards Earth Syst. Sci.

Discussion started: 27 February 2017

(c) Author(s) 2017. CC-BY 3.0 License.

\section{(c) (1)}
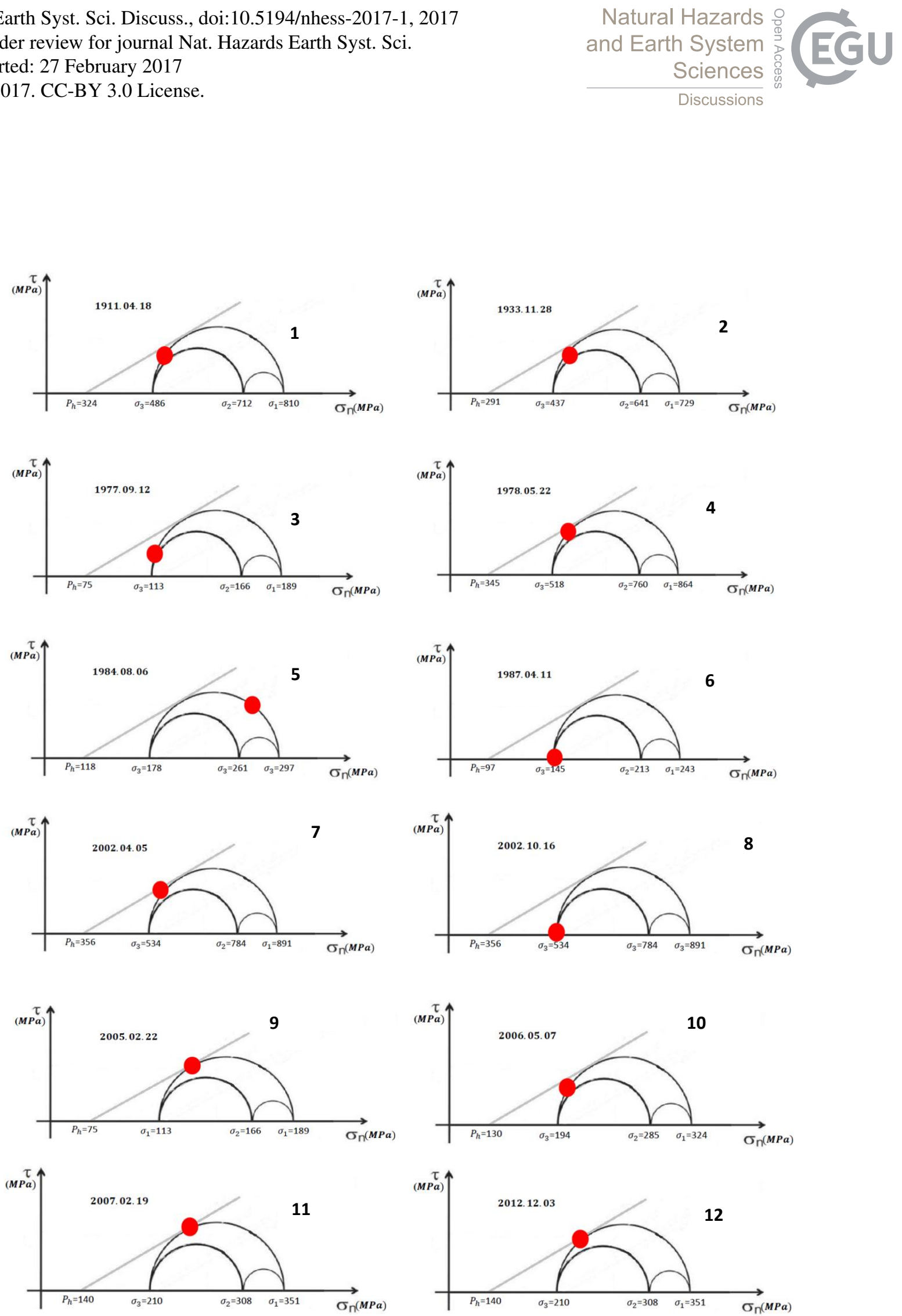

Figure 4. Mohr circles for Kuhbanan fault Earthquakes with a magnitude 5 and more according to Table 1. 
Nat. Hazards Earth Syst. Sci. Discuss., doi:10.5194/nhess-2017-1, 2017

Manuscript under review for journal Nat. Hazards Earth Syst. Sci.

Discussion started: 27 February 2017

(c) Author(s) 2017. CC-BY 3.0 License.

(c) (1)

\section{Natural Hazards and Earth System Sciences \\ Discussions}

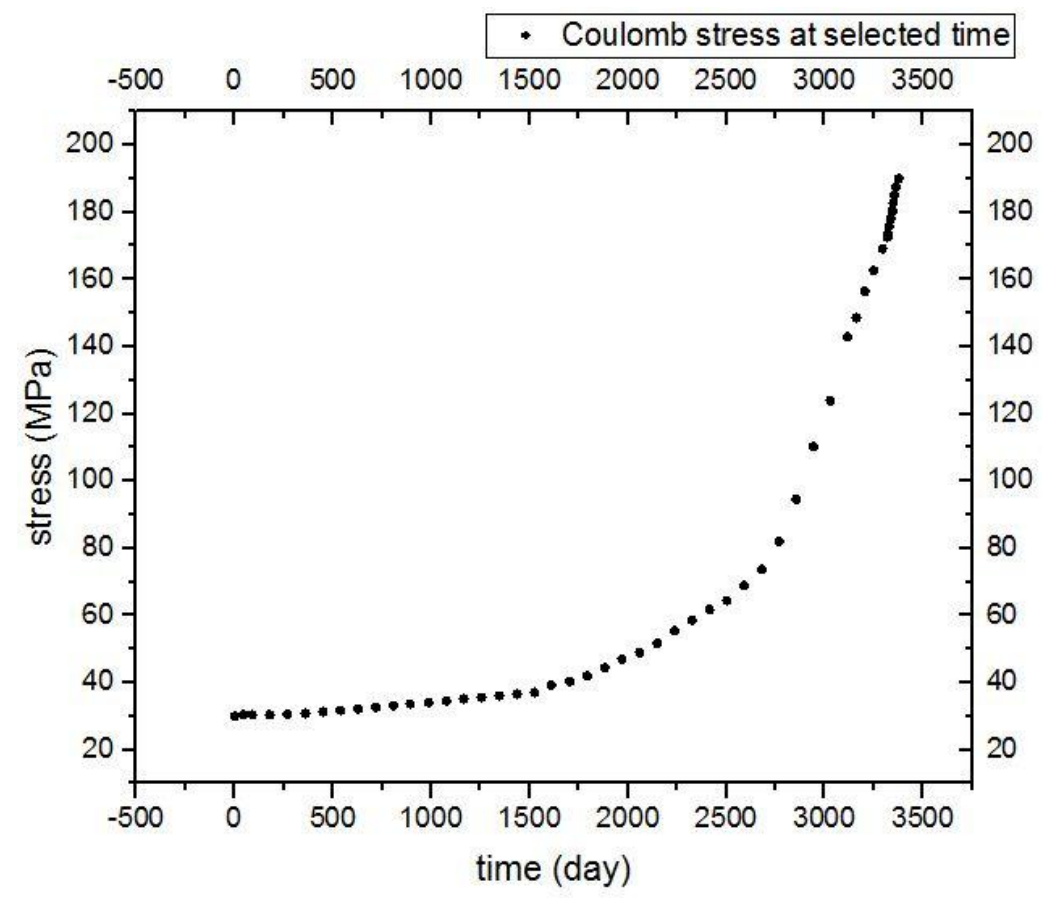

(a)

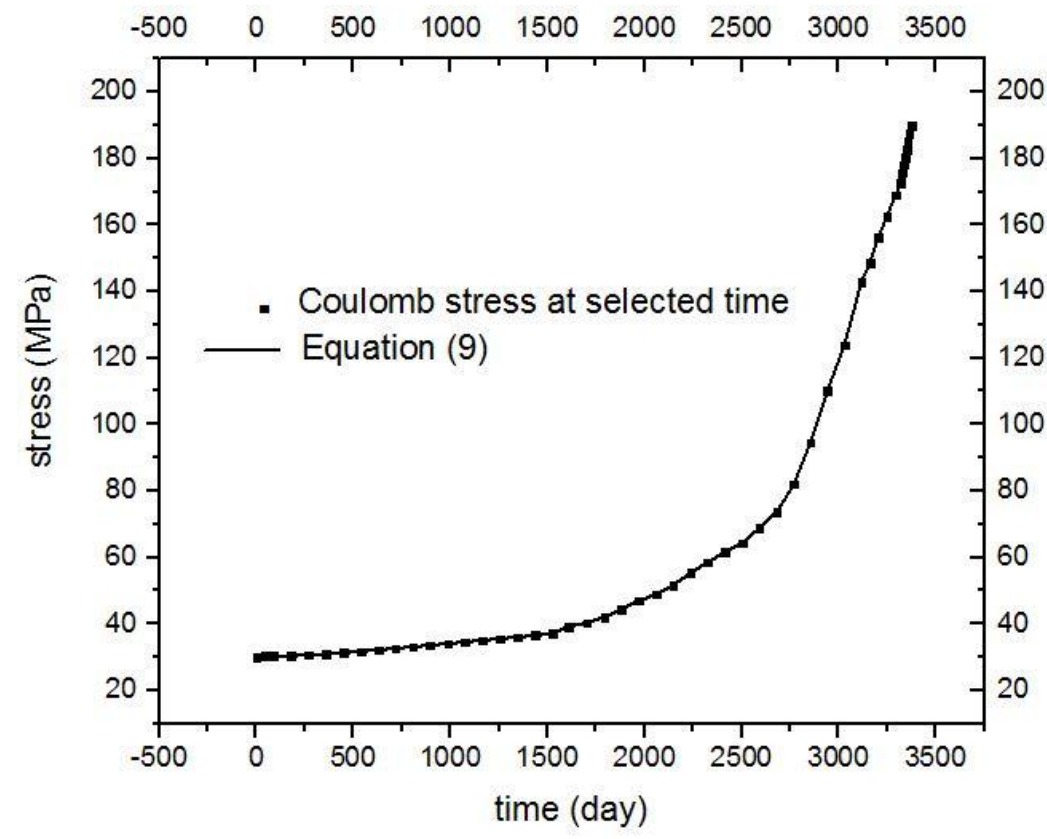

(b)

Figure 5. (a) : The Coulomb stress accumulation with selected times between two Earthquakes in the fault, (b) : Square symbol as in part (a) and the solid line is the best fit curve, indicating the polynomial relation of equation (9). 